\title{
EXPERT AT A DISTANCE
}

\section{BARBOSA DU BOCAGE AND THE PRODUCTION OF SCIENTIFIC KNOWLEDGE ON} AFRICA

Catarina Madruga

CIUHCT - Centro Interuniversitário de História das Ciências e da Tecnologia Universidade de Lisboa, Campo Grande 1749-016 Lisboa, Portugal cmmadruga@fc.ul.pt

\begin{abstract}
The career of José Vicente Barbosa du Bocage (1823-1907) as director of the Zoological Section of the Museu Nacional de Lisboa (National Museum of Lisbon) followed by the presidency of the Society of Geography of Lisbon is presented in this paper as an example of transfer of expertise between scientific fields, specifically from zoology to geography. Additionally, it explores the connection between scientific credit and political recognition, in the sense of the conflation of Bocage's taxonomical and zoogeographical work with the colonial agenda of his time. Although Bocage bimself never visited Africa, he was part of a generation of Africanists who were members of the Portuguese elite dedicated to African matters and considered exemplary custodians of the political and diplomatic Portuguese international position regarding its African territories.
\end{abstract}

Keywords: Expertise, zoogeography, science and empire, Africa, nineteenth century

\section{INTRODUCTION: BARBOSA DU BOCAGE, A NATURALIST QUA GEOGRAPHER}

In February 1883, the cover of the Diario Illustrado, a Lisbon daily newspaper, featured an article dedicated to José Vicente Barbosa du Bocage (1823-1907) a member of the Portuguese scientific and political elite, and a well-known zoologist. ${ }^{1}$ The illustrated text is

${ }^{1}$ Alberto Rocha, "Dr. Bocage," Diario Illustrado, (February 12) 1883, 3508: 1-2. For a periodisation and analysis of the biographical notes dedicated to Bocage see: Catarina Madruga, José Vicente Barbosa du Bocage (1823-1907). A construção de uma persona científica (Dissertação de Mestrado, Faculdade de Ciências da 
the first biographical note of "Dr. Bocage", signed Alberto Rocha who, given the level of details included and the personal relationship between writer and biographee, can be identified as Alexandre Alberto Rocha Serpa Pinto (1846-1900), a key figure of the Africanist movement. Published just two weeks after Bocage's appointment as the new Minister of Navy and Overseas, Serpa Pinto thus reinforced Bocage's authority and legitimation to occupy the demanding ministerial cabinet.

The biographical note described Barbosa du Bocage's life from his early days to his work as lecturer in Comparative Anatomy and Zoology, at the Polytechnic School of Lisbon, beginning in 1851, to the time when Bocage was the director of an important scientific museum in the nation's capital and the president of the Society of Geography of Lisbon, and of its African commission. In fact, after enrolling at the Polytechnic School, Bocage became responsible for the Zoological Section of the still incipient Natural History Cabinet of the school, and his role as director of the zoological collections was determining not only to shape his scientific contribution as the leading Portuguese zoologist of his time, but also to transform the museum into one of international visibility. Serpa Pinto further described Bocage's successful work at the museum, highlighting his many publications on new species from Angola's hinterland, and the recognition of his expertise by peers of Europe's finest museums of natural history, materialized in Bocage's invitation to become a member of many scientific societies.

The detailed explanation of the daily practices of a taxonomist and their dependence on relevant geographical information to identify zoological specimens was the preamble to the statement that any expert zoologist is "always a great geographer". 2 Thus, the expertise in the scientific activity of a zoologist is described as necessarily leading to a corresponding expertise in geography. In fact, zoogeography, or animal distribution studies, was then a developing field supported by the large-scale circulation of people and specimens possible through colonial administrations that connected institutions in Europe to territories all over the world. Taxonomists' main agenda in the second half of the nineteenth century was a shared interest in gathering information on the fauna of different regions, in a systematic endeavour to fill and complete nature's catalogues.

Universidade de Lisboa, 2013).

2 Rocha, "Dr. Bocage," p.1.

HoST - Journal of History of Science and Technology 11, pp. 57-74 DOI 10.1515/host-2017-0004 
The 1883 text's teleological tone tightly connected Bocage's scientific work and achievements to his recent competences as a politician and president of the Society of Geography of Lisbon. A deputy in the Low Chamber since 1879, and a Peer of the Kingdom since 1881, he now held an especially central position in the Portuguese colonial agenda. ${ }^{3}$ The constitution of collections sent to him by members of a network of collectors working at the hinterland gave Bocage a detailed understanding of the political organization of local Portuguese administration in different colonies, infrastructure problems, as well as knowledge of relationships established between collectors and different African workers and tribes. As a result, Bocage became well-informed in the daily affairs of the Portuguese colonies.

Literature on expertise, especially work by Harry Collins and Robert Evans, has tried to map and catalogue scientific expertise to better understand processes of truth acquisition and to define more closely demarcation criteria issues. ${ }^{4}$ In their work on tacit knowledge and how it relates to different stages of expertise, these authors proposed to differentiate between several stages of progressive expertise. This paper follows this line of enquiry by analysing the process of construction, accumulation, and acknowledgement of scientific expertise in Bocage's career. Collins and Evans also outlined a distinction between contributory and interactional expertise, the first being the last stage of accumulation of expertise in a specific field, and the second an ability to show competence in the language of field without actual practice on the same domain. By presenting the case of Barbosa du Bocage, this paper offers an example of an expert who make contributions in a specific field of knowledge (contributory expertise), in this case taxonomy and zoogeography, but who was also able to join in the discussion of a different community (interactional expertise), in this case, geography and colonial affairs. Specifically, this paper is interested in the question of referred expertise, another classification put forward by Collins and Evans for the circumstance when authority and acknowledgement of expertise in one field is transferred to a different field of knowledge, with a

\footnotetext{
${ }^{3}$ For a summary of Bocage's parliamentary positions see: Zélia Pereira, "Bocage, José Vicente Barbosa du (1823-1907)," in Dicionário Biográfico Parlamentar 18341910, coord. Maria Filomena Mónica, vol.1 (Lisboa: Imprensa das Ciências Sociais -Assembleia da República, 2004), pp. 395-397.

${ }^{4}$ Harry Collins and Robert Evans, Retbinking Expertise (Chicago: University of Chicago Press, 2007).
} 
different set of practices and rules, maintaining equivalent authority. 5

Moreover, this paper suggests Bocage as an example of the nineteenth century proximity between taxonomy and colonial studies. As Janet Browne has already stated, there is a tight connection between the colonial organization and the emphasis in geographical units of flora and fauna; on the one hand, the practice of specimen collecting was supported by imperial networks and colonial officials, and on the other, the same collections were the reification of territorial expansion and scientific expeditions were also a means to claim territory and sovereignty. ${ }^{6}$ Harriet Ritvo has furthermore claimed that the practice of naming new species was, in itself, part of a process of appropriation that is akin to colonial occupation. ${ }^{7}$ Therefore, taxonomy, zoogeography, and the context of the imperial strengthening were, in this period, associated and intertwined.

In the case of Barbosa du Bocage, his scientific career as a zoologist and museum director enabled the transfer of expertise from zoology to geography, as well as from African zoogeography to expertise in African colonial affairs, mediated by his top position in the Society of Geography and specifically in its African Commission. Because Bocage was president of the Society of Geography of Lisbon, between 1876 and 1883, he represented the nation's interests abroad in international conferences, and signed publications that contributed to his recognition as an Africanist. Whereas to be considered an Africanist meant usually being credited for having first-hand experience in the terrain and having served in the military or in administrative positions in the African colonies, in the unusual case of Bocage this appellation recognized his second-hand experience in colonial affairs built on his reputation as a naturalist qua geographer, to such an extent that I argue for the conflation of Bocage's taxonomical work with the colonial agenda of his time. Although Bocage never set foot in Africa, he became part of a generation of Portuguese Africanists,

\footnotetext{
5 On how to better operationalise this distinction, see Mads Goddiksen, "Clarifying interactional and contributory expertise," Studies in the History and Philosophy of Science, 2014, 47: 111-117.

6 Janet Browne, "Biogeography and empire," in Cultures of Natural History, eds. Nicholas Jardine, James Secord and Emma Spary (Cambridge: Cambridge University Press, 1996), pp. 305-321.

${ }^{7}$ Harriet Ritvo, "The Power of the Word: Scientific Nomenclature and the Spread of Empire," The Victorian Newsletter, 1990, 77: 5-8.

HoST - Journal of History of Science and Technology 11, pp. 57-74 DOI 10.1515/host-2017-0004
} 
i.e. members of the Portuguese elite who made African issues their subject of study. 8

In what follows, I analyse firstly the political context and institutional framework of the late half of the nineteenth century, emphasising the role of the Society of Geography of Lisbon in shaping the Portuguese colonial agenda, and building a generation of Africanists. Secondly, I consider the different phases of Bocage's work from a "novice" in the discipline to an established cabinet naturalist and his specific strategies of specialisation in the research collections in order to present scientific expertise as a result of a process of construction, accumulation, and acknowledgement. Thirdly, I argue how the transfer of expertise from zoology to geography became central to the connection between expertise in African zoogeography and in African colonial affairs, to such an extent that Bocage became recognized as a knowledgeable Africanist politician.

\section{THE AFRICAN QUESTION}

Portuguese African colonies were a central subject of debate from the second half of the nineteenth century onwards, particularly after 1875 , not only in the political but also in the public realm. The general public was confronted regularly with news and depictions of the Portuguese Africa in popular illustrated press such as the Occidente (1878-1915), while other daily newspapers included reports on parliamentary discussion centred in both general political aspects as well as more specific and technical issues of territorial demarcation or local administrative problems of the African colonies. While abolition of slavery practices and questions of market regulations were an important focus for political actors, literary and scientific circles discussed topics such as the economic, symbolic and political meaning of the relationship between metropolis and colonies. ${ }^{9}$

\footnotetext{
8 In this period, an Africanist could be someone who had an official position in the colonial administration, an explorer, but also someone who, like Bocage, João Andrade Corvo (1824-1890) or Luciano Cordeiro (1844-1900), was considered as custodian of the political and diplomatic Portuguese international position regarding its African territories by their scientific, political, and social position, even if they hadn't been to Africa.

${ }^{9}$ See Valentim Alexandre e Jill Dias (Coord.), O império africano: 1825-1890 (Lisboa: Estampa, 1998).
} 
Colonization of the African territories had never been an attractive life choice due to the hardships imposed by climate conditions and the lack of urban areas, both reinforced by the practice of sending prisoners to Africa as punishment for crimes perpetrated in the metropole. The Portuguese who occupied Angola in the 1870s inhabited mostly the coastal main cities and were usually engaged with small commerce or local administration, or were part of the military corps. Many were either public servants in diplomatic service, or naval and army officers who were required to do service overseas. 10

Motivated by the growing international geographical movement, concern gathered around the journalist Luciano Cordeiro to build the foundations of the Society of Geography of Lisbon, in 1875. At the end of 1876, when the publication of the Society of Geography of Lisbon's bulletin began, it had already gathered over two hundred individuals among correspondent and ordinary associates, and was organised into seven different sections.

As a scientific field, geography developed around geographical societies founded in most European metropoles, but also outside Europe, and in the countryside, mostly throughout the second half of the nineteenth century. The internal organisation of these societies makes clear that under the same roof meetings of various disciplines took place, including medicine, ethnology, natural history, meteorology, history. Geographical congresses also came to include sections in such diverse areas as ethnography, historical geography, meteorology, orology, hydrography, botany, mineralogy, and zoology. That is, geography was then considered an inclusive field of knowledge, including numerous scientific specializations. 11

Africa was the main agenda of the geographical societies of the great European powers for political and diplomatic concerns, to such an extent that geography represented an all-encompassing science holding together hydrographical, geological,

\footnotetext{
${ }^{10}$ For more on the political context see Charles Nowell, The Rose-Colored Map: Portugal's attempt to build an African empire (Lisboa: Junta de Investigações Científicas do Ultramar, 1982); Eric Axelson, Portugal and the Scramble for Africa, 1875-1891 (Johannesburg: Witwatersrand University Press, 1967); and Valentim Alexandre, "O Império Português (1825-1890): ideologia e economia," Análise Social, 2004, 169: 959-979.

11 On geographical societies, their constitution, and their relationship with the building of the nation-state and colonial discourse see, for instance: Dominique Lejeune, Les Sociétés de Géographie en France et l'expansion coloniale au XIXe siècle (Paris: Albin Michel, 1993).
}

HoST - Journal of History of Science and Technology 11, pp. 57-74 DOI 10.1515/host-2017-0004 
ethnographical, and medical knowledge about the colonies with the political and symbolic studies of historical geography. This is also visible in the organisational structure of the Society of Geography of Lisbon, where the composition of its different sections and its publications was mainly concerned with the colonial enterprise in all its political and scientific ramifications.

To spur the interest and attention of the public sphere towards the so-called colonial movement, especially in what concerned the national claims of territorial possessions in Africa, the Society of Geography of Lisbon instigated the assembly of data and the publication of cartographical and historical studies supporting Portugal's position in the diplomatic arena. In the name of the Society, Luciano Cordeiro signed multiple pamphlets, books, transcripts of historical documents, and newspaper articles arguing in favour of Portugal's political and diplomatic claims for some highly disputed regions such as the Congo or the Zambezi basins. ${ }^{12}$

Between 1880 and 1881, members of the Society of Geography of Lisbon gathered around prominent projects, such as the Commemoration of the 300th anniversary of the death of the poet Camões, author of the Lusíadas epic poem; the organisation of a national scientific expedition to the Serra da Estrela, continental Portugal's highest mountain, which included the first systematic studies of national fauna and flora; and the census questionnaire on Portuguese emigration abroad. Among them, one stood out: it was the organisation of a national subscription for the establishment of "Civilizing Stations" to be built in strategic places in the hinterland between the coasts of Angola in the west and Mozambique in the east. It was published as a leaflet titled To the Portuguese People by the African Commission of the Society of Geography of Lisbon, under the presidency of Barbosa du Bocage. ${ }^{13}$ It included an annex with a large map depicting a plan of occupation of the large strip of land between the two opposite coasts of Angola and Mozambique, coloured in rose, and which understandably came to be known as the "Rose Coloured Map". Bearing a strong visual impact, it materialised the main utopian vision around which Portuguese

\footnotetext{
${ }^{12}$ On the role of the Society of Geography of Lisbon in the 'Africanist' movement, see, for example: Ângela Guimarães, Uma Corrente do Colonialismo Português, a Sociedade de Geografia de Lisboa. 1875-1895 (Lisboa: Livros Horizonte, 1984), and Maria Emília Madeira Santos, Viagens de exploração terrestre dos portugueses em Africa (Lisboa: Junta de Investigações Científicas do Ultramar, Centro de Estudos de Cartografia Antiga, 1978).

${ }^{13}$ Sociedade de Geografia de Lisboa - Comissão Africana, Ao Povo Portuguez em nome da Honra, do Direito, do Interesse e do Futuro da Patria (Lisboa: Imprensa Nacional, 1881).
} 
citizens from all sectors united to defend what they perceived as the international threat to the historical position of Portugal in Africa. The Society of Geography of Lisbon therefore acted as a centre of production of geographic studies especially dedicated to colonial issues, which gathered much interest nationally, and which aimed to cause a big impression internationally through the translation into French and English of many historical documents as well as essays in which the role played by the Portuguese in Africa was asserted and made visible.

The discussion of the role of the Portuguese African territories in the political, symbolic and scientific arenas dominated the Portuguese agenda since the creation in December 1875 of the Society of Geography of Lisbon. In 1876, the international Brussels Geographic Conference revealed the interests of European powers in African southern territories. ${ }^{14}$ Almost a decade later the Conference of Berlin (November 1884 to February1885) gathered European powers, Russia and the United States of America, and set the tone for the period of the so-called "Scramble for Africa". 15 During this period Portuguese diplomacy was constantly having to defend Portugal's position on the basis of historical arguments for its presence in Africa. The justification and defence of vast lands in the African hinterland between the coasts of Angola and Mozambique, which to Portuguese eyes were seen as undisputedly theirs according to a claim of historical presence, were the subject of fierce contestation by European powers. Pressure on Portuguese diplomatic officials was increased especially by Britain and France, which had interests in the same regions. King Leopold's attention to the river Congo basin grew, and the International Association of the Congo was becoming increasingly known as an interest-free

${ }^{14}$ The 1876 conference was were the Belgian King Leopold II (1835-1909) first proposed the International African Association, which would become the International Association of the Congo, and later established as the Congo Free State.

${ }^{15}$ The Berlin international conference was convened by Otto von Bismarck (18151898), after Portugal's request for an international arbitration on the dispute with Great Britain to settle trade privileges in the basin of the Congo river, considered one of the most important commercial routes to the interior of Africa. This conference defined future norms to establish imperial domination and created the idea of "effective presence" to solve priority and determination of colonial borders of European authority in Africa. Notably, it would fall on Barbosa du Bocage, in his capacity as Minister of Foreign Affairs from the end of 1883 to 1886, to oversee negotiations with France and Britain on the matter of the Congo region. Although this is not the focus of this paper, the relationship between Bocage's biography and the African question was by no means over in 1883. The Portuguese delegates, under the instructions Barbosa du Bocage, counted among them Luciano Cordeiro, and Carlos Roma du Bocage (1853-1917), Bocage's son. 
association to defend freedom and identify and condemn slavetrade practices in the region. It was the dispute between Portugal and Britain over the commercial rights of navigation on the Congo River that precipitated the Conference of Berlin.

At the same time that 'Africa' became a political and diplomatic problem, it simultaneously provided the ground for experts of various fields to assert their scholarship. Many doctors, historians, engineers, and naturalists developed their scientific expertise around the main subject of Africa. The scientific and scholarly knowledge of Portuguese African territories, be it on zoology, botany, geology, ethnography, anthropology, and so on, together with its circulation in European networks legitimised the authority of Portuguese scholars and of their findings, at the same time that such studies contributed to assert the Portuguese presence in Africa, long before the Conference of Berlin, showing how science itself became a highly political subject. Such was the case of Barbosa du Bocage.

\section{TAXONOMICAL WORK AND ZOOGEOGRAPHY CONSTITUTIVE BLOCKS OF THE COLONIAL AGENDA}

\section{First steps in building a specialized zoological museum}

José Vicente Barbosa du Bocage was born in 1823, in Funchal, on the Atlantic isle of Madeira. His parents were both from liberal families and his uncle, the general José Ferreira Pestana (17951885) was a Professor at Coimbra University, a Minister for Overseas and a Peer of the Kingdom. Barbosa du Bocage was to follow in his footsteps. He graduated in Medicine from the University of Coimbra, and came to Lisbon as a physician. He then applied as substitute Lecturer for the Polytechnic School of Lisbon in 1849, and was appointed main Lecturer of the 8th Chair (Zoology and Comparative Anatomy) in 1851.16 This position implied that Bocage also became director of the Zoological Section of the School's natural history cabinet and laboratory. Taking into his hands the promotion and upkeep of such a museum, Bocage started working on the inventory of the Portuguese fauna. The few existing studies in Portuguese zoology were out of date, and due to several decades of social conflicts in the political arena, the existing

${ }^{16}$ For more on the teaching of natural history at the Polytechnic School of Lisbon, see Daniel Marques, O Ensino e a Investigação em Zoologia e em Botânica na Escola Politécnica de Lisboa, 1837-1911 (Ph.D. disertation, Universidade Nova de Lisboa, 2014). 
collections were unkempt and in a poor state. ${ }^{17}$ Bocage began by examining the existing collections in the Academy of Sciences of Lisbon, and in the Royal Cabinet. In 1857, he produced a memoir on the Portuguese Ibex, in which he suggested a new species of ibex, later acknowledged as a subspecies of the Pyrenean Ibex. ${ }^{18}$

In 1859, he asked for permission from the board of the School to go on a visiting tour of similar European museums and scientific institutions. ${ }^{19}$ From this official journey he bought materials for the museum and the laboratory of zoology, and several recent scientific publications to prompt the library of zoology. He also began fruitful relationships with naturalists, museum curators and directors. From then on, Bocage relied on a network of correspondents who assisted in the identification of specimens and new species, provided the material for his publications, and sent him doubles from their own collections. He also realized that, much more than a didactical exhibit for the purposes of the School, what was important was to create the infrastructure for a research museum. He therefore began to take significant steps to build a specialised zoological research laboratory and museum. In the report of his 1859 tour, he advocated building reference collections of the groups already present in the museum rather than to purchase random specimens of different groups. His curatorial plan envisaged specialisation in certain zoological groups more than the acquisition of general collections. Bocage believed that in this way the museum would "rapidly grow in richness and scientific importance". 20

In order to implement his research program Bocage was in need of large reference collections. He counted on his peers in European museums, but they were of no help in what related to build specific collections of Portuguese overseas territories. To circumvent such a problem, Bocage published, in 1862, a set of instructions for collecting, preparing, and shipping zoological specimens to the Museum in Lisbon, ${ }^{21}$ in order to equip prospective collaborators

\footnotetext{
17 On the existing zoological collections, see Luís Ceríaco, A Evolução da Zoologia e dos Museus de História Natural em Portugal (Ph.D. thesis, Universidade de Évora, 2014).

18 Hermann Schegel (1804-1884), a correspondent of Bocage's, considered it the subspecies Capra pyrenaica lusitanica (Schlegel, 1872).

${ }^{19}$ See José Vicente Barbosa du Bocage, "Relatorio," Diario do Governo (2 January), 1860, 1: 5-6. On the role of travels in the development of expert knowledge, see Ana Simões, Ana Carneiro, Maria Paula Diogo eds. Travels of Learning. A Geography of Science in Europe (Berlin: Springer, 2003).

20 Bocage, "Relatorio," p. 5 (my translation).

${ }^{21}$ José Vicente Barbosa du Bocage, Instrucções praticas sobre o modo de colligir, preparar HoST - Journal of History of Science and Technology 11, pp. 57-74 DOI 10.1515/host-2017-0004
} 
with the means to contribute significantly to the expansion of the museum's collections. The instructions were distributed in several Portuguese colonies, and received by local governments, alongside with a recommendation that copies should be distributed to employees of the colonial administration. ${ }^{22}$ This marked the beginning of a regular and systematic shipment of zoological specimens from overseas to engross the museum's collection. The "Instructions" were also the document where Bocage's ideas for the consolidation of zoology in Portugal as a scientific discipline took shape for the first time. Bocage aimed at creating an important research museum with a specialized field of expertise that surpassed local interest, and which would succeed to be recognised accordingly.

\section{AFRICA IN LISBON}

The next step was for the Lisbon museum to be validated and acknowledged as a centre of production of new knowledge. To accomplish this, Bocage realised the possibilities of focusing research on African fauna. He expected that after sending the 'Instructions' to many Local Governments in several outposts of the Portuguese colonies, regular shipments from distant territories would follow, while he stayed in Lisbon and laid the foundation for a research museum.

Bocage began receiving shipments from Angola's hinterland, from a keen army officer Francisco António Pinheiro Bayão (18331883). In 1864, Bocage published his first description of an African species, the Rana Bragantina in French, in the Revue et Magasin de Zoologie, describing a frog shipped by Bayão. ${ }^{23}$ Angola and the Congo were still unexplored regions, and even several decades afterwards, in 1895, Bocage could state that most European museums did not have «more than the occasional authentic specimens of the herpetological fauna» of these regions. ${ }^{24}$ This was indeed a geographical region to explore scientifically with promising results and political implications.

\footnotetext{
e remetter productos zoologicos para o Museu de Lisboa (Lisboa: Imprensa Nacional, 1862). 22 Luiz Antonio Figueiredo, Indice do Boletim Official da provincial d'Angola (Loanda: Imprensa do Governo, 1864), p.130 (see bulletin N. 503).

${ }^{23}$ José Vicente Barbosa du Bocage, "Note sur un nouveau batracien du Portugal "Chioglossa Lusitanica» et sur une grenouille nouvelle de l'Afrique Occidentale «Rana Bragantina»," Revue et Magasin de Zoologie, 1864, 16: 248-254. Today Rana bragantina is considered a synonym of Hoplobatrachus occipitalis (Günther, 1858). ${ }^{24}$ José Vicente Barbosa du Bocage, Herpétologie d'Angola et Du Congo (Lisboa: Imprensa Nacional, 1895), p. IV (my translation).
} 
Throughout the span of more than forty years, the number of Bocage's collaborators abroad reached dozens. Most of them shipped specimens from the territories under the Portuguese Crown. As the scientific publications of the museum increased, the possibility to argue for a larger budget for more focussed expeditions also improved. At the turn of the century several collectors were or had been contracted officially by the museum, directed and instructed to collect systematically, study and send to Lisbon any valuable zoological materials. Almost all of them also used the opportunity to collect botanical and geological collections for scientific institutions in Lisbon, Coimbra and Oporto, which meant they had a basic training and access to literature in order to provide accurate observations alongside the specimens. Bocage maintained correspondence with them and sometimes requested particular species or groups depending on the specific problem or species he wanted to study in detail.

In 1866, José Alberto de Oliveira Anchieta (1832-1897) signed a contract with the Portuguese government as a natural history collector. While Anchieta was in Africa, he was to explore the coast and the hinterland of Angola. In time, his zoological shipments would yield more than one hundred new species. His relationship with Bocage was fruitful, his letters to Lisbon were ripe with information on the geographical details of where specimens were caught, but they also contained vivid descriptions of the social and political background of life in the hinterland. ${ }^{25}$ Anchieta, as well as the rest of the network of collaborators of the museum, therefore contributed to the enlargement of the Zoological Section's museum and to its specialised status as a centre of knowledge where African zoogeography was being built and recognized as expert knowledge.

An additional mark of Bocage's research program was the directive that the museum's assistant naturalists focus on a specific taxonomic group. Félix Brito Capelo (1828-1879), appointed assistant in 1861, for example, specialised in ichthyology and invertebrates, and he published, between 1864 and 1878, 27 scientific papers and, posthumously, the Catalogue of Fishes of Portugal (1881). António Roberto Guimarães (1843-1882?) and Baltazar Machado da Cunha Osório (1855-1926) continued the line of work in ichthyology and invertebrates. Capelo published his first paper on African species in 1864, in Portuguese, in the periodical Memorias

25 The extensive correspondence between Anchieta and Bocage is analysed in António Banha de Andrade, O Naturalista José de Anchieta (Lisboa: Instituto de Investigação Científica Tropical, 1985).

HoST - Journal of History of Science and Technology 11, pp. 57-74 DOI 10.1515/host-2017-0004 
da Academia Real das Sciencias. ${ }^{26}$ Thus, the small group of naturalists under Bocage worked systematically on selected groups of animals, resulting in specialisation and the acquisition of expertise in specific topics.

Bocage himself studied different zoological groups, and his main work was on vertebrates, focussing mainly on the large African region of Angola. In this sense, he became an expert on zoogeography, specialising in a region and in its characteristics. Expressively, of his more than 150 scientific papers and published listings, more than half focus specifically on Angola, to the extent that at the beginning of the twentieth century one of the museum's rooms was dedicated solely to Angola. This specialisation resulted from the systematic exploration of the Angolan hinterland, carried out by Anchieta, from 1866 on. While surveying the hinterland and in constant contact with Lisbon, Anchieta became a trusted and privileged connection between Lisbon's zoological museum and Angola. Bocage's expertise in the Angolan regions was only possible due to his endeavours, and his work made it possible for Bocage to become an accomplished cabinet naturalist, accumulating evidence from the Portuguese empire in Lisbon, and making it known internationally.

As Bocage intended, the specialisation acquired by the Lisbon museum attracted the attention of the scientific community of natural history curators. To maintain a strong network of scientific correspondents was a feature of the naturalists' routine. ${ }^{27}$ Briefly, in his daily work of specimen identification, the zoologist had first to identify its main characters, and then to compare it either with a reference collection, illustrations, or written descriptions of the genera or species. Unknown or unfamiliar specimens, with very few exemplars in European collections, raised many doubts. In this last case, the holotype must be examined otherwise the author of the first description or the curator of the museum holding a specific specimen or collection had to be consulted. As a result of Bocage's publications, correspondence network, and collectors in the Africa

\footnotetext{
${ }^{26}$ Félix Brito Capelo, "Descripção de tres especies novas de crustáceos da Africa Occidental e observações acerca do «Penoeus Bocagei», Johnson, especie nova dos mares de Portugal," Memorias da Academia das Sciencias de Lisboa, 1865, 3 (2): 1-11. ${ }^{27}$ On the system of trade and reward, see Catarina Madruga, "The Zoological Collections of the Museu de Lisboa and the networks of scientific correspondence and exchange (1858-1898)" in The Circulation of Science and Technology: Proceedings of the 4th International Conference of the ESHS, Barcelona, 2010, ed. Antoni Roca-Rosell (Barcelona: SCHCT-IEC, 2012), pp. 928-933; and A. M. Lucas, "Specimens and the Currency of Honour: the Museum Trade of Ferdinand von Mueller," Historical Records of Australian Science, 24 (2013):15-39.
} 
hinterland, the Zoological Section of the National Museum of Lisbon would become a relevant node in terms of the European network of natural history museums.

Bocage's career illustrates the rise and consolidation of an impressive network of collectors and correspondents denoting the accumulation of expertise and its recognition by peers. In his early years, still establishing himself in the profession, he approached his correspondents humbly. In his first appeal to Albert Gunther (1830-1914), zoologist of the Natural History section of the British Museum, London, Bocage profited from a connection with a friend in common, writing to Gunther that "with no one here whom I could consult in this very difficult study, and privy of the indispensable books, it would be for me a real joy to be able to benefit from your illumination." 28 A few years later, Bocage visited London to meet Gunther in person. The two naturalists entertained a long epistolary relationship and the later letters are addressed to "My dear friend". Some years after, it was the turn of Bocage to be approached by a young naturalist, Eduardo Boscá y Casanoves (1843-1924). Boscá introduced himself mentioning a common friend, before asking for Bocage's advice on an African batrachian with which he was unfamiliar. ${ }^{29}$ Moreover, in 1864, Bocage was honoured with the naming of a new mollusc species, the Helix bocageana (Crosse, 1864). ${ }^{30}$ The attribution of specific names to new species honouring fellow naturalists was, and still is, a common feature of the taxonomic process, and a mechanism of symbolic trade and recognition inside the community. In this manner, by the late 1870 s Bocage's expertise had increased along with his symbolic value in the community of European naturalists.

\section{FROM TAXONOMY TO ZOOGEOGRAPHY}

Less than ten years after his first works on African fauna, Bocage was ready to benefit from the accumulated collections mainly shipped by Anchieta, and from his national and international recognition as an expert on African fauna. In December 1873, he

\footnotetext{
${ }^{28}$ Quote from the correspondence between Bocage and Gunther, in José Vicente Barbosa du Bocage (1823-1907) to Albert Gunther on 2 April 1863. DF ZOO/200/1/183-195 Library and Archives, The Natural History Museum, London (my translation).

${ }^{29}$ Quote from the correspondence from Boscá to Bocage, 11 July 1876. Historical Archives of the Museums of the University of Lisbon, AHMB CE.B.24 (my translation).

30 The original description is found in Hippolyte Crosse, "Diagnoses de Mollusques terrestres nouveaux," Journal de Conchyliologie, 1864, 12: 282-286.

HoST - Journal of History of Science and Technology 11, pp. 57-74 DOI 10.1515/host-2017-0004
} 
wrote to the Ministry of Navy and Overseas, his friend Andrade Corvo, requesting funding for the project of a three-volume work entitled Fauna of Portuguese Western African Possessions (Fauna das possessões da Africa Occidental Portuguesa). ${ }^{31}$ This project, Bocage argued, would showcase the progress of Anchieta's work in Angola and would also present to a larger audience the results of the investment of the Portuguese government in the study of its colonies. It would have three volumes, respectively on mammals, birds, and reptiles. This work aimed at presenting the collections and research of the Lisbon museum, and match in importance the systematic work on the Mozambique region Naturwissenschaftliche Reise nach Mossambique done by Wilhelm Peters (1825-1883), working for the Berlin Museum für Naturkunde. The Ministry of Navy and Overseas replied positively, and Barbosa du Bocage began without delay the compilation of material for the first part called Ornithologie d'Angola. It was published in two instalments, in 1877 and 1881. The first in 1877 included an Introduction signed by Bocage on the 7 July, the symbolic date of the departure of Serpa Pinto and Hermenegildo Capelo (1841-1917) in the first Society of Geography of Lisbon's scientific exploration of African rivers. In 1895, Bocage finally published Herpétologie d'Angola et Congo, the second section of his project, but he would never finish the last tome dedicated to Mammals. ${ }^{32}$ With this ambitious project Bocage drew a more detailed picture of the Angolan landscape. In this specialized way, he contributed to the knowledge of Portuguese Africa's largest overseas territory, indicating that science played a highly political role in such a context. Probably because they never had a unifying title, the two books Ornithologie and Hérpetologie have always been taken as two separate projects, and his work on African mammals has so far been overlooked. However, I argue that the Fauna project should be considered as a coherent life-long project of national identity and imperial construction, via the taxonomical practice and its zoogeographical results.

Bocage's scientific interest in African territories was corroborated and co-constructed by Portugal's political interest in the same territories. The hinterland of Angola was the geographical region that had most occupied Barbosa du Bocage, and consequently was the highlight of the museum's collections, and the focus of his

31 Historical Archives of the Museums of the University of Lisbon, AHMB DIV130, Bocage to Ministry of Navy and Overseas (2 December 1873).

32 The Historical Archives of the Museums of the University of Lisbon hold a substantial part of Bocage's scientific papers, including drafted manuscripts, and the indexed cards of the Mammalogie d'Angola et Congo book project. I thank the archivist Vitor Gens for bringing some of these documents to my attention. 
publications. When in 1873 he proposed to publish a large opus on the zoogeography of the region of Angola and Congo, he aimed to establish Portuguese scientific domain over these territories. Thus, even in the period before the Brussels Geographic Conference, Bocage and the rest of the political and scientific elite were already interested in Africa as a subject matter. This interest was coconstructed with the political increased interest in the defence of what has been called as Portugal's "Third Empire."

As has been shown, Bocage acquired recognition as an expert in Africa, at the same time as African matters and the colonial issues therein develop and gained international attention. Many in his generation, and most of his friends and colleagues wrote in newspapers or published books where they articulated the generation's feelings about the colonial administration and Portugal's diplomatic positions regarding Europe and its empire. Although he never participated in the political periodical press, as President of the Society of Geography of Lisbon, Bocage was summoned to the public arena and embarked on a stronger participation in the construction of the colonial discourse on Africa. This discourse was helped by the accumulation of taxonomic knowledge in relation to its geographical distribution which had been at the forefront of Bocage's agenda for more than ten years. Going back to Collins and Evans' classification scheme this paper has shown how Bocage revealed different levels of expertise on colonial territories depending on the domain he was working on. On Angola's zoogeography he was a contributor, publishing scientific papers and contributing to further knowledge on the subject, and mentoring others on the same field. On colonial affairs and other geographical details on Portuguese Africa he may be considered as an interactional expert since he commanded the language and jargon being used, most obviously while presiding over the sessions of the Society of Geography of Lisbon.

In the 1883 biographical note, Serpa Pinto adduced various arguments to validate Bocage's recent position as Minister of Navy and Overseas, and inscribed Bocage's path into a road of civic contribution, highlighting his scientific proficiency as a characteristic connected with the ability to politically intervene in colonial administration, attributing a political sense to his life path. Although Bocage's specific fields of expertise, taxonomy and zoogeography, were not directly connected with an economic or profitable use of the colonized territories, I have shown how his scientific works were nevertheless charged with the African political agenda. Bocage's own scientific agenda corroborated the program of legitimation of the Portuguese presence in central Africa and 
was, at the same time, supported by the political background. I argue that this process was a result of a move from transferred expertise (from zoology to geography) to expertise in the political realm, in the sense that Bocage's taxonomical and zoogeographical work was conflated with the colonial agenda of his time, a process which was built long before the Conference of Berlin.

\section{CONCLUSIONS: EXPERT AT A DISTANCE}

This paper discusses the main steps in Bocage's career that led him from a professor of Zoology and Comparative Anatomy at the Polytechnic School in Lisbon to an internationally reputed zoologist with an acknowledged scientific expertise in taxonomy and zoogeography of the Portuguese African possessions. Due to the then broad definition of geographical knowledge, Bocage's expertise in African vertebrates was seen as the result of a transferrable expertise from one science to the other, a process embodied in Serpa Pinto's statement that a zoologist is «always a great geographer». The institutionalisation of geographical societies in the nineteenth century was deeply connected with the building of empires and a very political subject. Thus, this paper agrees with Serpa Pinto's perception that the Society of Geography of Lisbon endowed Bocage with an additional legitimisation as a political actor dedicated to the African question. However, this paper goes beyond Serpa Pinto's claim and argues that Bocage's scientific domains of taxonomy and zoogeography, and his research in these specific fields, expressively stated in his project for a Fauna of Portuguese Western African Possessions, were in fact what identified him after 1873 as an engaged actor of the African question. In the nineteenth century, the demanding context of progressive imperialism determined the agenda of many scientific practices, which in turn took advantage and constructed themselves around this historical situation. This was the case of the study of animal and plant geographic distribution, and this paper argues that it was the context of the broad definition of the domain of geography that paved the way for the referred expertise in many fields in the career of José Vicente Barbosa du Bocage. 


\section{ACKNOWLEDGEMENTS}

This research is part of my Ph.D. project in progress at the University of Lisbon carried out with the support of a grant from the Faculty of Sciences of the University of Lisbon, and of a doctoral grant, awarded by national funds of FCT-MCTES, via CIUHCT - Interuniversity Research Centre for the History of Science and Technology, University of Lisbon [UID/HIS/00286/2013]. This paper refers to previous findings from my M.Sc. dissertation José Vicente Barbosa du Bocage (18231907). A construção de uma persona cientifica, Faculty of Sciences, University of Lisbon, 2013, and includes research presented in the 9th STEP Meeting [Science and Technology in the European Periphery], Lisbon, in September 2014. I would like to thank the reviewers and the editors for helpful comments on earlier versions of this paper. Publishing expenses of this article were paid also in the context of the project UID/HIS/00286/2013. 